\title{
Malachite green (triarylmethane dye) and pyceze (bronopol) induced histopathological and biochemical changes in the liver of stinging catfish Heteropneustes fossilis (Bloch, 1794)
}

\author{
ASHVANI KUMAR SRIVASTAV AND D. ROY \\ Fish Physiology and Toxicology Laboratory, Department of Zoology, S. M. M. Town Post-Graduate College \\ Ballia - 27 7001, Uttar Pradesh, India \\ e-mail:ashvanisri.21@gmail.com
}

\begin{abstract}
Malachite green is one of the most widely used therapeutant and disinfectant in aquaculture. Pyceze is a pharmaceutical alternative to malachite green with bronopol as its active ingredient. The present study evaluated the effect of malachite green and pyceze on liver histology and selected biochemical parameters indicating liver function in Heteropneustes fossilis. Fishes were exposed to sublethal doses of malachite green and pyceze and the biochemical parameters viz., serum bilirubin, serum glutamic oxaloacetic transminase (SGOT) and serum glutamic pyruvic transminase (SGPT) were estimated. After 24 and $96 \mathrm{~h}$ exposure, tissue samples of liver were fixed for histological studies. The level of serum bilirubin, SGOT and SGPT increased significantly after 24 and $96 \mathrm{~h}$ of exposure to both malachite green and pyceze. Hepatocytes of liver exposed to both malachite green and pyceze were irregularly shaped, with vacuolated cytoplasm, enlarged nucleus and ruptured cell membrane. However, these symptoms were more prominent in the liver tissues of fish exposed to malachite green than those exposed to pyceze. The present study clearly indicated that the detrimental effects are less pronounced in case of pyceze exposure than that of malachite green exposure. Thus, pyceze can be considered as a relatively safe alternative to malachite green as a therapeutant in aquaculture.
\end{abstract}

Keywords: Heteropneustes fossilis, Histology, Liver function, Malachite green, Pyceze

Malachite green is an extensively used biocide in aquaculture worldwide. It is highly effective for the control of fungal infections and for control of other external parasites, such as protozoans, trematodes and larvae of parasitic crustaceans of fish and fish eggs (Hoffman and Mayer, 1974; Bills et al., 1977; Alderman, 1985; Schnick, 1988). It is used as a food colouring agent, food additive, a medical disinfectant, antihelminthic product and also as dye in silk, wool, jute, leather, cotton, paper and acrylic industries (Culp and Beland, 1996). However, due to the risks it poses to the consumers of treated fish, including its effects on the immune system, reproductive system and its genotoxic and carcinogenic properties (Fernandes et al., 1991; Rao, 1995; Gouranchat, 2000), malachite green has now become a highly controversial compound (Alderman and Clifton-Hadley, 1993). Malachite green is reported to cause carcinogenesis, mutagenesis, chromosomal abnormalities and physiological changes in animals (Omoregie et al., 1998; Srivastava et al., 2004). It also acts as respiratory poisoning, damaging the cell's ability to produce energy to derive vital metabolic processes (Werth and Boiteaux, 1967; Ross et al., 1985).

Though the use of this dye has been banned in several countries and not approved by U. S. Food and
Drug Administration (Chang et al., 2001), due to its low cost, ready availability and efficacy (Schnick, 1988) and due to lack of a proper alternative, it is still being used in many parts of the world. Recently, a phamaceutical alternative to malachite green, pyceze with bronopol as its active ingredient has been developed in U. K. It is being used for the treatment of fish and their ova and appears to be a safe and effective replacement for malachite green in prevention of fungal infections (Cawley, 1998; Pottinger and Day, 1999; Hardwick, 2000; Kaijser et al., 2001). The $\mathrm{LC}_{0}, \mathrm{LC}_{50}$ and $\mathrm{LC}_{100}$ values of malachite green and pyceze were estimated by Chaturvedi et al. (2012). The behavioural effects of both the chemicals were also observed by Srivastav and Chaturvedi (2012). However, there is not enough information available on the effect of these chemicals on the liver function in fish. Therefore, the aim of the present study was to check the effects of malachite green and pyceze on the histology and function of liver in the freshwater catfish Heteropneustes fossilis.

Live specimens of adult $H$. fossilis $(30.25 \pm 1.25 \mathrm{~g}$; $12.75 \pm 1.50 \mathrm{~cm})$ were collected from local fish market and were acclimated to the laboratory conditions for ten days. Fishes were fed daily with a mixture of oil cake and 
rice bran (1:1) and also with a mixture of wheat flour and ground dried shrimp (1:1). The water quality parameters in the experimental systems were analysed as per standard methods (APHA, 2005). Stock solutions of both malachite green and pyceze (95 to $98 \%$ purity, Sigma) were prepared in distilled water. Sublethal dose of one fifth of $\mathrm{LC}_{50}$ value of both the chemicals were used for the study i.e., $0.24(\mathrm{mg} \%)$ for malachite green and $0.42(\mathrm{mg} \%)$ for pyceze. A group of 15 fishes (5 fishes per 101 glass jar in triplicates) were exposed to the test concentrations of the chemicals along with a control group. Fishes were starved $24 \mathrm{~h}$ prior to sampling and no feeding occurred $96 \mathrm{~h}$ following the exposure. At 24 and $96 \mathrm{~h}$, postexposure, fishes from both control and treated groups were sacrificed and blood samples were collected from the caudal artery by severing the caudal peduncle for estimation of bilirubin, serum glutamic oxaloacetic transminase (SGOT) and serum glutamic pyruvic transminase (SGPT) as described by Basu et al. (1986). At 24 and $96 \mathrm{~h}$ post-exposure, fishes were also sampled for liver histology. Fish were dissected and tissue samples of liver were fixed in aqueous Bouin's fluid, for histological studies. The fixed tissues were dehydrated in ascending series of alcohol, embedded in paraffin wax, sections were cut at $6 \mu$ thickness, stained with haematoxylin/ eosin, observed under compound microscope and photomicrographs were taken.

The water quality parameters recorded in the experimental systems were: $\mathrm{pH} 7.8 \pm 1.2$, dissolved oxygen $8.40 \pm 1.60 \mathrm{mg} \mathrm{l}^{-1}$, BOD $16.20 \pm 1.85 \mathrm{mg} \mathrm{l}^{-1}$, hardness $136.60 \pm 4.70 \mathrm{mg} \mathrm{l}^{-1}$ as $\mathrm{CaCo} 3$ and chloride $6.90 \pm 0.95 \mathrm{meq}^{-1}$.

Detrimental effects were observed in the liver due to malachite green and pyceze toxicity after 24 and $96 \mathrm{~h}$ of exposure. Morphologically liver is a bilobed structure situated in the anterior part of the abdomen, posterior to the pericardial cavity. The structure of the liver consists of homogeneous mass of polyhedral hepatocytes arranged in irregular cords, a billiary system formed of intracellular bile canaliculi and few sinusoids. The hepatocytes have granular cytoplasm with a distinct nucleus stained intensively with hematoxylen/eosin (Fig. 1). The intracellular bile canaliculi anastomose to form typical bile duct. The liver tissue on the whole showed necrotic changes in the fishes exposed to both the chemicals. Hepatocytes greatly increased in size and were found irregularly shaped with vacuolated cytoplasm and enlarged nuclei (Fig. 2 and 3). The cell membrane of most of the hepatocytes was ruptured and fused with those of adjacent cells forming wide intracellular spaces. The liver cord arrangement was disrupted and the connective tissue was damaged (Fig. 4 and 5). However, these changes

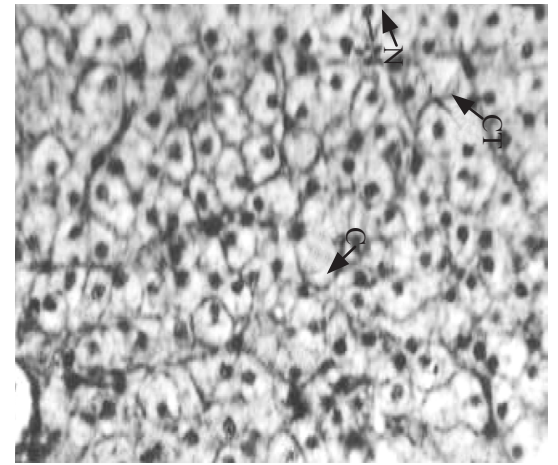

Fig. 1. Photomicrograph showing histological section of liver of $H$. fossilis control fish showing normal hepatocytes with thin cytoplasm and prominent nuclei (H\&E; x600)

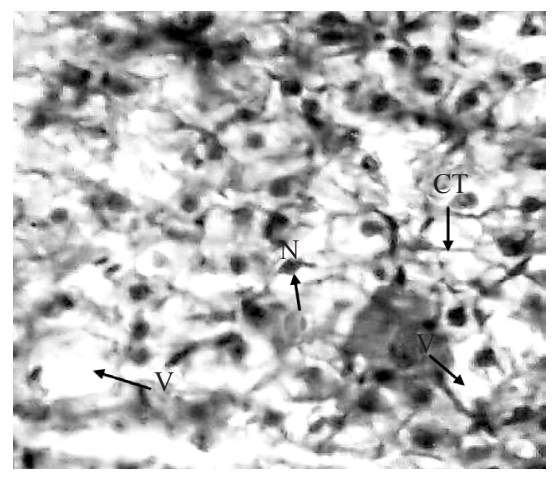

Fig. 2. Histological section of liver of H. fossilis, treated with malachite green after $24 \mathrm{~h}$ showing vacuolated hepatocytes $(\mathrm{V})$, disrupted cell walls, broken connective tissue (CT) and enlarged nucleus (N) (H\&E; x600)

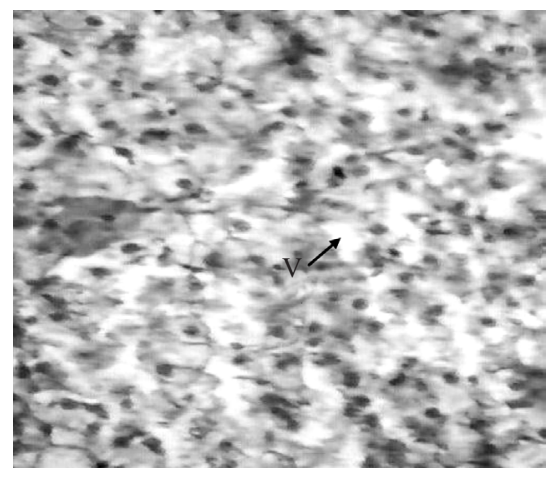

Fig. 3. Liver section of $H$. fossilis, treated with pyceze after $24 \mathrm{~h}$ showing vacuolated hepatocytes (V) (H\&E; x600)

were more prominent in fish exposed to malachite green than those exposed to pyceze. The levels of bilirubin, SGOT and SGPT increased significantly after 24 and $96 \mathrm{~h}$ exposure. Levels of bilirubin, SGOT and SGPT recorded were, in control fish: $1.12 \pm 0.04 \mathrm{mg} \%, 38 \pm 1.63$ unit $100 \mathrm{ml}^{-1}$ and $34 \pm 1.82$ unit $100 \mathrm{ml}^{-1}$; in fish exposed 


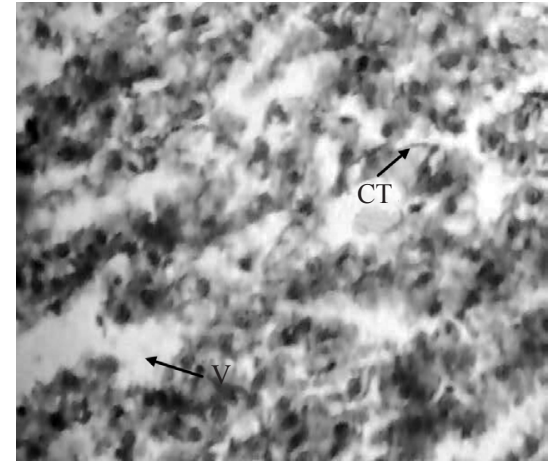

Fig. 4. Liver of H. fossilis, treated with malachite green after $96 \mathrm{~h}$ showing vacuolated hepatocytes $(\mathrm{V})$; disrupted cell walls and broken connective tissue (CT) (H\&E; x600)

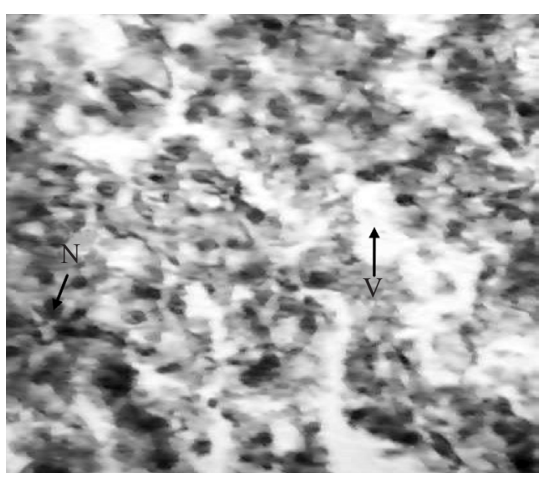

Fig. 5. Liver section of $H$. fossilis, treated with pyceze after $96 \mathrm{~h}$ showing vacuolated hepatocytes $(\mathrm{V})$ and enlarged nucleus $(\mathrm{N})(\mathrm{H} \& \mathrm{E} ; \mathrm{x} 600)$

to malachite green for $24 \mathrm{~h}: 1.24 \pm 0.04 \mathrm{mg} \%, 48 \pm 1.63$ unit $100 \mathrm{ml}^{-1}, 40 \pm 0.81$ unit $100 \mathrm{ml}^{-1}$; in fish exposed to pyceze for $24 \mathrm{~h}: 1.19 \pm 0.03 \mathrm{mg}^{\circ}, 42 \pm 2.16$ unit $100 \mathrm{ml}^{-1}$, $38 \pm 2.58$ unit $100 \mathrm{ml}^{-1}$; in fish exposed to malachite green for $96 \mathrm{~h}: 1.32 \pm 0.03 \mathrm{mg} \%, 56 \pm 2.16$ unit $100 \mathrm{ml}^{-1}$, $52 \pm 1.82$ unit $100 \mathrm{ml}^{-1}$ and in fish exposed to pyceze for 96 h: $1.26 \pm 0.02 \mathrm{mg}^{2}, 48 \pm 1.63$ unit $100 \mathrm{ml}^{-1}, 46 \pm 1.82$ unit $100 \mathrm{ml}^{-1}$ respectively (Table 1 ).

Acute bioassay toxicity tests with fish have played a major role in aquatic hazards and risk assessments, especially at a "screening" level of evaluation (Margaret et al., 1995). Treatments of H. fossilis with malachite green and pyceze resulted in marked histopathological changes in the liver, showing hypertrophy and vacuolisation of hepatocytes. Similar histopathological changes have also been observed in other fishes exposed to various toxicants (Shastry and Sharma, 1978, 1981; Goel and Garg, 1980; Gopal et al., 1991; Srivastava and Srivastava, 1993; Pandey et al., 1994;). However, little information is available regarding toxicity of dyes on the fish liver, especially for pyceze. In rainbow trout, sinusoidal congestion and focal necrosis, as well as mitochondrial damage and dilation of endoplasmic reticulum, have been observed in the liver, after repeated exposure to malachite green (Gerundo et al., 1991).

Different views have been expressed about the mechanism of toxicant action on liver. According to Goel and Garg (1980), the decreased activity of lactic dehydrogenase in the liver and kidney led to hepatorenal necrotropic changes in the freshwater fish, Channa punctatus treated with 2, 3-4-triaminoazobenzene. Gopal et al. (1991) have also attributed histopathological changes in the liver to disturbances in enzymatic activity and elevation of blood cholesterol level. Srivastava and Srivastava (1993) are of the opinion that the catfish, $H$. fossilis exposed to chlordecone tries to adapt to stress of the extrametabolic load by compensatory hypertrophy of the liver cells, as characterised by increase in size of hepatocytes, hypertrophy of nuclei and vacuolisation of cytoplasm. They attributed it to the depletion of glycogen and infiltration of lipids in the liver cells followed by migration of cytoplasm to the periphery. Srivastava et al. (1998), reported presence of large vacuoles, cytoplasmic swelling, distortion of nuclei and pyknosis in the liver tissue of fish exposed to malachite green which corroborates with the results of the present study.

The present study clearly showed the comparative toxic effects of malachite green and pyceze on the liver tissue of $H$. fossilis. The levels of bilirubin, SGOT and SGPT increased significantly at 24 and $96 \mathrm{~h}$, post-exposure to both malachite green and pyceze. Increase in the serum enzyme and bilirubin levels recorded could be attributed to damage in hepatic cells and biliary obstructions, which caused metabolic changes and alteration in serum enzymes and bilirubin levels.

Table 1. Changes in biochemical parameters after malachite green and pyceze exposure

\begin{tabular}{llllll}
\hline \multirow{2}{*}{ Parameters } & \multirow{2}{*}{ Control } & \multicolumn{4}{c}{ Treatments } \\
\cline { 3 - 6 } & & Malachite green $(24 \mathrm{~h})$ & Pyceze $(24 \mathrm{~h})$ & Malachite green $(96 \mathrm{~h})$ & Pyceze $(96 \mathrm{~h})$ \\
\hline Bilirubin $(\mathrm{mg} \mathrm{\% )}$ & $1.12 \pm 0.04$ & $1.24 \pm 0.04$ & $1.19 \pm 0.03$ & $1.32 \pm 0.03^{*}$ & $1.26 \pm 0.02$ \\
SGOT (unit 100 ml-1) & $38 \pm 1.63$ & $48 \pm 1.63^{*}$ & $42 \pm 2.16$ & $56 \pm 2.16^{* * *}$ & $48 \pm 1.63^{*}$ \\
SGPT (unit100 ml-1) & $34 \pm 1.82$ & $40 \pm 0.81$ & $38 \pm 2.58$ & $52 \pm 1.82^{* * *}$ & $46 \pm 1.82^{* *}$ \\
\hline
\end{tabular}

All values are mean \pm SE $(n=4) ; * p<0.05, * * p<0.02, * * * p<0.01 ;$ SGOT:Serum glutamic oxaloacetic transminase; SGPT:Serum glutamic pyruvic transminase 


\section{Acknowledgements}

Authors are grateful to Dr. S. J. Srivastava, Department of Zoology, S. M. M. Town P. G. College, Ballia, for his contribution to the formatting of this paper as per guidelines.

\section{References}

Alderman, D. J. 1985. Malachite green: a review. J. Fish Dis., 8: $289-298$.

Alderman, D. J. and Clifton-Hadley, R. S. 1993. Malachite green: a pharmacokinetic study in rainbow trout, Onchorhynchus mykiss (Walbaum). J. Fish. Dis., 16(4): 297-311.

APHA 2005. Standard methods for the examination of water and wastewater, $24^{\text {th }}$ edn. American Public Health Association. Washington, $801 \mathrm{pp}$.

Basu, R. N., Ray, K., Ichhpujani, R. L. and Khanna, K. K. 1986. Manual on health laboratory procedures for district level Technicians, National institute of Communicable Diseases, Delhi, p. 114-116.

Bills, T. D., Marking, L. L. and Chandler Jr. J. H. 1977. Malachite green: its toxicity to aquatic organisms, persistence and removal with activated carbon. Investig. Fish Contr., 75: $6 \mathrm{pp}$.

Chang-Jun,C.,Daniel,R.D. andCarl,E.C.2001.Biotransformation of malachite green by the fungus Cunninghamella elegans. Appl. Environ. Microb., 67(9): 4358-4360.

Chaturvedi, N., Srivastav, A. K., Abhinav and Srivastava, S. J. 2012. Studies on acute toxicity of malachite green and pyceze on certain freshwater fish, Cyprinus carpio, Colisa fasciatus and Heteropneustes fossilis. J. Interacad., 16(1): 147-153

Cawley, G. D. 1998. Bronopol: an alternative fungicide to malachite green. J. Fish Vet., 3: 79-81.

Culp, S. J. and Beland, F. A. 1996. Malachite green: a toxicological review J. Am. Coll. Toxicol., 15: 219-238.

Fernandes, C., Lalitha, V. S. and Rao, V. K. 1991. Enhancing effects of malachite green on the development of hepatic preneoplastic lesions induced by $\mathrm{N}$-nitrosodiethylamine in rats. Carcinogenesis, 12: 839-845.

Gerundo, N., Alderman, D. J., Cliton-Hadley, R. S. and Feist, S. W. 1991. Pathological effects of repeated doses of malachite green: a preliminary study. J. Fish. Dis., 14: 521-532.

Gpel, K. A. and Garg, V. 1980. Histopathological changes produced in the liver and kidney of Channa punctatus after chronic exposure to 2, 3, 4-triaminoazobenzene. Bull. Environm. Contam. Tocicol., 25: 330-334.

Gopal, K., Ram, M. D., Gupta, G. S. D. and Anand, M. 1991. Cellular bioassay of fish Channa punctatus exposed to pesticides. J. Zool. Res., 4(1\&2): 11-18.
Gouranchat, C. 2000. Malachite green in fish culture (state of the art and perspectives) Bibliographic studies. Ecole Natl Veterinaire ENVT Nantes France, 142 pp.

Hardwick, J. 2000. Pyceze an alternative to malachite green TRTO1.Trout News (CEFAS), 30 July, p. 28-29.

Hoffman, G. L. and Meyer, F. P. 1974. Parasites of freshwater fishes. TFH Publications, Neptune, New Jersey.

Kaijser, B., Torud, B. and Sorgaard, M. 2001. Replacing malachite green. Fish Fash. Int., 28(7): 25.

Margaret, W., Taussaint, T. R., Shed, W. H., Leather, G. R. and Vanders, S. 1995. A comparison of standard acute toxicity tests with rapid-screening toxicity tests. Toxic Chem., 14: 907-915.

Omoregie, E., Ofojekwu, P. C., Anosike, J. C. and Adeleye, A. O. 1988. Acute toxicity of malachite green to the Nile tilapia, Oreochromis niloticus (L) J. Aquac. Trap., 13(4): 233-237.

Panday, A. K, Mohamed, M. Peer and George, K. C. 1994. Histopathological alterations in liver and intestine of Liza parsia (Hamilton-Buchanan) in respons to mercury toxicity. J. Adv. Zool., 15(1): 18-24.

Pottinger, T. G. and Day, J. G. 1999. A Saprolegnia parasitica challenge system for rainbow trout:assessment of pyceze as an antifungal agent for both fish and ova. Dis. Aquat. Organ., 36(2): 129-141.

Rao, K. V. K. 1995. Inhibition of DNA synthesis in primary rat hepatocyte cultures by malachite green: a new liver tumor promoter. Toxicol Lett., 81(2-3): 107-113.

Ross, L. G., Ward, K. M. H. and Ross, B. 1985. The effects of formalin, malachite green and suspended solids on the respiratory activity of rainbow trout Salmo giardneri Richandson. Aquac. Fish. Manage., 16: 129-138.

Sastry, K. V. and Sharma, S. K. 1978. The effect of endrin on the histopathological changes in the liver of Channa punctatus. Bull. Environ. Contam. Toxicol., 20: 674-677.

Sastry, K. V. and Sharma, S. K. 1981. Daizinon induced histopathological and haematological alterations in a freshwater teleost Ophiocepahalus punctatus. Ecotoxicol. Environ. Saftey, 5: 329-340.

Schnick, R. A. 1988. The impetus to register new therapeutants for aquaculture. Prog. Fish Cult., 50: 190-196.

Srivastava, A. K. and Srivastava, A. K. 1993. Chlordeconeinduced histopathological changes in the liver of the freshwater catfish Heteropneustes fossilis. J. Ecotoxicol. Environ. Monit., 3(4): 247-250.

Srivastava, A. K., Sinha, R., Singh, N. D., Srivastava, S. D. 1998. Histopathological changes in a freshwater catfish, Heteropneustes fossilis following exposure to malachite green. Proc. Nat. Acad. Sci. India, Sec. B. Biol. Sci, 68: $253-257$ 
Srivastava, S. J., Gupta, A. K., Srivastava, P. K. and Abhinav 2004. Acute toxicity of malachite green to fingerlings of common carp, Cyprinus carpio. Biol. Memoirs., 30(2): 120-121.

Srivastav, A. K. and Chaturvedi, N. 2012. Effects of malachite green (Triarylmethane dye) and pyceze (Bronopol) on the behaviour of certain freshwater fish Colisha fasciatus
(B1.\& Schn.), Cyprinus carpio (Linn.) and Heteropneustes fossilis (Bloch). J. Exp. Zool. India, 15(2): 477-479.

Werth, G. and Boiteaux, A. 1967. The toxicity of the triphenylmethane dyestuff malachite green, as an uncoupler of oxidative phosphorylation in vivo and in vitro. Arch, fur. Toxicol., 23: 82-103. 